\title{
Program ODOPOS ( One Day One Problem One Solution) In Realistic Mathematics-Based Online
}

\section{Diah Sulistiyowati \\ Nur Fauziyah \\ Fatimatul Khikmiyah}

Departement of Mathematic, Faculty of Teaching and Trining, Universitas Muhammadiyah Gresik

diaaahs34@gmail.com

\begin{abstract}
ABSTRAK
The purpose of this research is to develop ODOPOS (one day one problem one solution) program in realistic mathematic that is based online. By application of realistic mathematics is expected to have students the ability to understand mathematics in real life.

The sample of this study is 33 students at V grade of Elementary School of Muhammadiyah Manyar at 2019-2020 academic years. The research instrument is a pretest-posttest test and student response questionnaire sheet.

Result of the study: (1) Development of ODOPOS (one day one problem one solution) program in realistic mathematic based online is: (a) Analyze stage, includes analysis of student characteristics and material analysis (b) Design stage, there is a use case diagram that is: home, profile, log in, summary and examples of problems, exercises, scores and class progress (c) Development stage is developing the ODOPOS program design based on the use case diagram. (d) Implementation stage, is the result of the development ODOPOS program being applied in learning for one week (e) evaluation stage, is giving a pretest-posttest test and student questionnaire response sheet (2) there is an increase in student achievement $84,84 \%$. The students get an n-gain score of 0.7 for the high category from the use of the ODOPOS (one day one problem one solution) program. (3) Students responses to the ODOPOS program, based on the content criteria, the result is $93.49 \%$ or very feasible, the language criteria $98.98 \%$ or very feasible and the presentation criteria $97.72 \%$ or very feasible.
\end{abstract}

Keywords: Realistic mathematic, ODOPOS program, e-learning, student achievement

\begin{abstract}
Penelitian ini adalah penelitian yang bertujuan untuk mengembangkan ODOPOS (satu hari satu masalah satu solusi) program dalam matematika realistis berbasis online. Dengan penerapan matematika realistis, siswa diharapkan memiliki kemampuan untuk memahami matematika dalam kehidupan sehari-hari. Contoh dalam kajian ini adalah 33 siswa kelas V SD Muhammadiyah Manyar pada tahun akademik 20192020. Instrumen penelitian yang digunakan adalah tes Pretest-uji coba dan lembar respons kuesioner siswa.

Hasil penelitian yang diperoleh adalah: (1) pengembangan ODOPOS (satu hari satu solusi masalah PNE) program dalam matematika realistis berbasis online, yaitu (a) fase analisis mencakup analisis karakteristik dan analisis materi siswa (b) tahap desain berisi penggunaan diagram kasus meliputi: rumah, profil, log in, ringkasan dan contoh pertanyaan, praktek pertanyaan, kelas dan kemajuan Class (c) tahap pengembangan yang mengembangkan ODOPOS desain program sesuai dengan penggunaan diagram kasus (d) tahap pelaksanaan, yang merupakan hasil pengembangan program ODOPOS yang diterapkan dalam pembelajaran selama satu minggu. (e) tahap evaluasi, termasuk memberikan tes uji-coba pra-uji coba dan lembar jawaban kuesioner siswa. (2) terdapat peningkatan hasil pembelajaran sebesar 84,84\% siswa yang memperoleh keuntungan sebesar 0,7 dengan kategori yang tinggi dari penggunaan program ODOPOS. (3) tanggapan siswa terhadap program ODOPOS berdasarkan kriteria konten yang diperoleh hasil 93,49\% atau sangat layak, kriteria bahasa 98,98\% atau sangat layak dan kriteria presentasi diperoleh hasil 97,72\% atau sangat layak.

Kata kunci: matematika realistis, program ODOPOS, pembelajaran online, hasil pembelajaran Matematika.
\end{abstract}

Keywords: realistic mathematics, ODOPOS program, online learning, mathematics learning outcomes 


\section{INTRODUCTION}

One characteristic of mathematics learning that is commonly used is abstract mathematics . With this abstract nature students often have difficulty in learning and understanding mathematical concepts well. Mathematical abstractness because its basic objects are abstract, which are facts, concepts, operations, and principles (Murdiani, 2018). Mathematical abstract characteristics along with other features that are not simple, cause mathematics is not easy to learn, and in the end many students are less interested in mathematics. Most students find it difficult to apply mathematics in situations of daily life or the real world. There are other things that cause students difficulties in mathematics is because mathematics learning is less meaningful and gives an impression to students. Teachers in class learning do not relate to students' experiences and students are not given the opportunity to rediscover and construct mathematical ideas themselves (Jenning and Dunne, 1999) .To help students understand the mathematical concepts that are abstract then needed something tangible, one of which is to link the learning of mathematics to real-life learners. Linking real-life experiences of children with mathematics

learning process. In ODOPOS program is accessible learners are online so that students can learn to use information technology and communications are growing rapidly at this time. In the world of education learning online is known also by distance learning or otherwise known as e-learning and hybrid learnin $\mathrm{g}$.

According to Nasution (2011) E-learning is a learning process that utilizes information and communication technology (ICT) systematically by integrating all learning components across space and time with guaranteed quality. Currently e-learning is widely used in the world of education for the learning process such as Moodle, Google classroom, Edmodo, Schoology, etc.

In addition to e-learning there is online learning that is used today, namely Hybrid learning . Hybrid learning is learning that combines various approaches in learning, namely face-to-face learning, computer-based learning and online learning . Hybrid learning is often used in Teacher Professional Education (PPG) such as spada, bright space, weblogs etc. With online learning, students are expected to be able to learn wherever and whenever and take advantage of the mathematical ideas in classroom learning is very important so that learning can be meaningful and give an impression so that students enjoy learning more (Soedjadi, 2000). P en dekatan math today known as realistic mathematics.

The realistic mathematics approach is an approach that aims to motivate students to understand mathematical concepts by linking these concepts to problems in daily life (Nin Gsih, 2014). Therefore, the problem is use $\mathrm{d}$ a lam realistic mathematics learning approach must have relevance to the real situation that is easily understood and imagined by the students so as to improve understanding of the structures of mathematics learners. With the application of realistic mathematics this aims to make the questions about mathematics become easier for students to understand .

At the moment we are also familiar with the Realistic Nalaria Mathematics Competency (KMN $R$ ) of Indonesia, it is a form of mathematics development program in the real world. Therefore , in this study a different program was carried out from K M N R namely the ODOPOS ( one day one problem one solution ) program in realistic mathematics based online. This ODOPOS program will be developed as an alternative for students to do the realistic

technology and communication that are developing at this time.

ODOPOS program dala $m$ realistic mathematicsbased online i ni i ngin foster $b$ udaya to learners that cultural familiarize implemented in a realistic mathematics continue every day with the use of technology and communication .

Therefore, the aim of this study was to develop a program ODOPOS ( one day one problem one solution) in mathematics-based realistic online .

\section{METHODS}

This type of research is Research and Development (R\&D) related to research and development. The subjects of this research were 33 students in grade V of SD Muhammadiyah Manyar. Muhammadiyah Manyar Elementary School address at Jl. Amuntai No. 1 Ponganganrejo, Yosowilangun, Kec. Manyar Kab. Gresik This research was conducted in the odd semester of the 2019-2020 school year.

The research procedure used in this study uses the ADDIE model which stands for Analysis, Design, Development, Implementation, and Evaluations . According to (Tegeh, 2014) the ADDIE model consists of five steps, namely: 


\section{Analysis Phase (Analyze )}

The analysis phase ( Analyze) includes the following activities: a) analyzing the competencies required of the students. b) analyzing the material in accordance with the competence tuntukan c) analyzing the characteristics of learners about their learning capacities, skills, knowledge, attitudes yes ng owned learners and relevant. The analysis phase involves three questions that must be answered thoroughly. First, what competencies must be mastered by students after using product development? Second, according to the competencies required and the characteristics of the students, what materials need to be developed? Third, what are the characteristics of students who will use this development product?.

\section{Stage Design ( Design )}

The planning stage ( Design ) is carried out with the following reference frame: a) for whom is the learning designed? (Learners); b ) how can the subject matter or skills be well studied? (learning strategies); c ) what skills do you want to learn? (competence); d) how do you determine the level of mastery learning that has been achieved? (assessment and evaluation). Based on these questions, then in designing learning focused on three activities, namely choosing material that is in accordance with the demands of competence and characteristics of students, learning strategies that are applied and the forms and methods of assessment and evaluation used.

\section{Development Phase ( Development )}

At the development stage (development ) activities undertaken are translating design specifications into physical form, so that these activities produce prototypes of development products. The activities at this stage of development, among others: pencaraian and collection of all references or sources required for the carrier gan material, manufacture of tables and charts supporting, setting the layout, making of pictures illustration, pen g etikan, preparation of evaluation and others.

\section{Implementation Phase ( Implementation )}

Activities at the implementation stage are the results of development applied in learning to find out their effects on the quality of learning which include attractiveness, efficiency, and effectiveness of learning. Prototype of product development needs to be tested in real time in the field to get a picture of the level of attractiveness, efficiency, and effectiveness of learning.

\section{Stage Evaluation ( Evaluation )}

The final stage is conducting an evaluation which includes formative evaluation and summative evaluation. Formative evaluation is carried out to collect data for each stage used for improvement and summative evaluation is carried out at the end of the program to determine its effect on the quality of broad learning and student learning outcomes. In development research generally only formative evaluation is carried out, because this type of evaluation is related to the development research stage to improve the production of the resulting development. Data collection methods used in this study are 1) the test method, which uses pretest and posttest $\mathrm{t}$. Pretest is used to know the learning outcomes of students before being treated, while the posttest is used to find out how the learning outcomes of students after being treated. 2) the questionnaire method, the questionnaire used was the student response questionnaire to find out the students' responses to the ODOPOS program developed

Research instruments include 1) Learning outcomes test sheet, used to find out the mastery of the research subject's concepts on the subject delivered after using the ODOPOS program . This test is presented at the pretest and posttest . Pretests are given to students before using the ODOPOS program, while posttests are given after students use the ODOPOS program . The form of the test used was the form of a description test of 10 questions. 2) pieces of questionnaire responses of learners , Sheets learners' questionnaire responses provided to learners who mengik $\mathrm{u}$ ti piloted ODOPOS to determine the response and the opinion of users of the program ODOPOS seen from the criteria of content, language and presentation .

Data analysis techniques used in this study are 1) analysis of student learning outcomes tests include analysis of completeness of learning outcomes taken from the posttest value obtained by completeness of student learning has been achieved if obtained (Kemendikbud, 2014). K emudian analyzed de ngan using the formula : Then to increase student learning outcomes are measured from the value of pretest da $n$ posttest learners, in the following manner: Learning outcomes are stated to increase if the Gain value is moderate based on the following table.

Table 3.1 Interpretation of Gain values Gain Value (g)Category 


\begin{tabular}{l} 
High \\
\hline Enough \\
\hline Less \\
\hline
\end{tabular}

(Hake, 1998)

2) Analysis of student response results data, Analysis of student response results data is processed using the Guttman scale. Each question is assertive, meaning only gives two choices of answers, is "Yes" and "No". Respondents' answers, in this case the students have a value of 1 for the answer "Yes" and a value of 0 for the answer "No". From the assessment of students the field trials were analyzed descriptively quantitatively. The assessment data is analyzed using the formula: Criterion score $=$ number of items $\mathrm{x}$ highest score of each item $\mathrm{x}$ number of respondents

The percentage results are interpreted based on percentage criteria.

Tabel Interpretation 3.2 Percent Response Positive Students

Percentage of answers Category

\begin{tabular}{ll}
\hline $81-100$ & Very decent \\
\hline $61-80$ & Worthy \\
\hline $41-60$ & Decent enough \\
\hline $21-40$ & Inadequate \\
\hline $1-20$ & Not feasible \\
\hline
\end{tabular}

Student responses to the ODOPOS program are said to be feasible if the category is feasible or very feasible.

\section{RESULT}

$\mathrm{H}$ acyl $\mathrm{p}$ enelitian that have been made about the program ODOPOS ( one day one problem one solution ) in the realistic mathematics-based online learners class V SD Muhammadiyah Manyar namely ODOPOS program development using ADDIE models comprises the steps as follows :

1) Analysis Phase (Analyze )

The ODOPOS (one day one problem one solution) program in online -based realistic mathematics which is the subject of research is grade V of SD Muhammadiyah Manyar Gresik. The problem faced is to identify what is needed in producing the conceptual design of the ODOPOS program (one day one problem one solution) in realistic mathematics based online, because the
ODOPOS program (one day one problem one solution) in online based realistic mathematics is a learning design that is new to learning mathematics. Therefore, the purpose of this study is as a preliminary analysis and conceptual design for the ODOPOS (one day one problem one solution) program in online -based realistic mathematics . This research is expected to foster students' interest in learning mathematics in a fun way.

2) Stage Design ( Design )

Stage Design ( Design ) is the second phase of this development research. In this stage there is a Use Case Diagram namely:

- Home covers about ODOPOS and Learning Instructions

- Profile includes Name, Class, ODIPOS NIPD, photo and school origin

- Logs in include Anonym (only see a summary of the material), user name and password

- Realistic problems include the problems that appear and the solution is hidden if clicked then the solution will appear.

- Material summary contains brief material

- The exercises contain questions about appearing questions, then students answer then students upload answers and then grades appear.

- Value contains about ranking value

- Class Progress contains the progress of learning based on graphs

3) Development Phase (Development )

The development phase of the program design has been made in accordance with the use case diagram which will later be implemented to students . Students can start learning by logging in first, to learn learning material students can see in the material summary. Meanwhile, to see examples of questions and discussion students can see in the menu examples of realistic questions, in practice questions students will answer the questions and upload the answers. In addition students can also change their profile with the profile menu.

4) Phase Implementation ( I mplementation )

The fourth stage is the implementation phase or field trial. The ODOPOS web implementation was tested on Grade 5 students at SD Muhammadiyah Manyar on July 22, 2019. Before testing it directly, we gave 4 days online and 1 day face to face, 4 days online ie Monday, Tuesday, Wednesday and Thursday, and for one-time meeting agreed on Saturday.

The activities carried out are as follows: 
at meeting $1=$ online learning - answers uploaded - correction

At meeting 2 = online learning - answers uploaded - correction

- $\quad$ At meeting $3=$ online learning - answers uploaded - correction

- $\quad$ At meeting $4=$ online learning - answers uploaded - correction

- $\quad$ At Meeting $5=$ Discussion of Answers

Then at the end the grades appear and performance progress will appear from the learning of each meeting.

\section{5) Stage Evaluation ( Evaluation )}

At the evaluation stage will be carried out prestest and posttest and questionnaire responses of students. Based on the results obtained as many as 33 students in carrying out the achievement is not complete. Next is the posttest, here are the data obtained from the posttest :

Table 4.1 Posttest Results of Muhammadiyah Manyar Elementary School Students

Number of students Information

\begin{tabular}{ll}
26 & $\mathrm{~T}$ \\
\hline 7 & $\mathrm{TT}$ \\
\hline
\end{tabular}

Ketera $\mathrm{n}$ bro $: \mathrm{T}=$ Complete

$$
\mathrm{TT}=\text { Not Complete }
$$

Table 4.2 n-Gain Results for Muhammadiyah Manyar Elementary School Students

Number of students $\mathrm{K}$ belonging to the selected

28 Is

$5 \quad$ High

And the results of the Posttest of students given after using the ODOPOS program (one day one problem one solution) showed that $78.78 \%$ of students were declared complete with a Posstest value $\geq 2.67$. In addition, based on an increase in learning outcomes, it is known that $84.84 \%$ of students get a gain value between $0.3-0.7$ or fall into the medium category, and as many as $15.16 \%$ of students get a gain value $\geq 0.7$ or include into the high category. Then the data obtained from the response of students as follows:

Table 4.3 Data Results of Students Response to ODOPOS Program

Criteria Percentage Category
Content $\quad 93.49 \%$ Very decent

Language $\quad 98.98 \%$ Very decent

Presentation $97.72 \%$ Very decent

Based on the above data, the results of an assessment of the ODOPOS program are based on the content criteria, which yields $93.49 \%$ or very feasible, the language criteria is $98.98 \%$ or very feasible, and the presentation criteria that yield $97.72 \%$ or very feasible. . In accordance with the statement of Riduwan (2012) the media is said to be feasible if from each - each criterion both content, language, and presentation results get $61 \%$ or in the feasible and very feasible categories. Therefore based on the results of ODOPOS program students' responses have been declared very feasible.

\section{CONCLUSIONS, DISCUSSION AND RECOMMENDATIONS}

Based on the discussion above, in this study it can be concluded that: 1) Development of the ODOPOS program ( one day one problem problem solution ) in online -based realistic mathematics, namely (1) The analysis phase includes the analysis of students' characteristics and material analysis (2) The design stage contains a diagram use cases include: home, profile, log in , summary and sample questions, practice exercises, grades and class progress (3) Development stage, i.e. developing ODOPOS program design in accordance with the use case diagram (4) Implementation Phase which results from the development of ODOPOS program applied in learning for one week. (5) Evaluation Phase, includes providing pretest-posttest tests and student questionnaire responses sheets. 2) There is an increase in learning outcomes by $84.84 \%$ of students getting a gain of 0.7 with a high category from the use of the ODOPOS program (one day one problem one solution) . 3) The students' responses to the ODOPOS program (one day one problem one solution) based on the content criteria obtained results of $93.49 \%$ or very feasible, the language criteria of $98.98 \%$ or very decent and the presentation criteria obtained results of $97.72 \%$ or very feasible.

Before the research "ODOPOS ( One Day One Problem One Solution ) Program in Online- Based Realistic Mathematics " there was a previous study related to this research, a study by Denny and Haris ( 2015 ) entitled "Utilization of Weblogs in Virtual Environments in Realistic Mathematics 
Education" which discusses about the use of weblogs for realistic mathematics learning processes. S edangkan in this study that is doing the learning of mathematics realistic and see if the results of learners can be increased with the use of learning online are using the web ODOPOS.

The recommendation of this study is that learning ODOPOS (one day one problem one solution) can be continued as an alternative to improve students' mathematics learning achievement .

\section{REFRENCES}

Denny and Haris. 2015. Utilization of Weblogs in Virtual Realistic Mathematics Education . http://www.scrib.com/using-weblog-on the virtual-educational-mathematics-realistic environment (accessed 12 May 2020).

Jennings, Sue \& R, Dunne. 1999. Math Stories, Real Stories, Real-life Stories. http://www.ex.ac.uk/telematics/T3/mathsact ar01.htm .

Murdiani, 2018 . Improving Motivation and Learning Outcomes Adding Fractions Through the Cooperative Learning Model Type Make A Match Grade IV Students of SDN Hariang, Banua Lawas District, Tabalong Regency . Sogacious Scientific Journal of Education and Social Vol.4 No. January 2-June 2018.

Nasution, 2011. Various Approaches in the Learning and Teaching Process . Jakarta: PT. Earth Literacy.

Ningsih, Seri. 2014. Realistic Mathematic Education : Alternative Models of School Mathematics Learning. JPM IAIN Antasari Vol.01 No. 2 p. 73-94.

Riduwan, Mohamad. 2012. Mathematical Planning and Development. Medan: PT. SOFMEDIA

Soedjadi. 2000. Tips on Mathematics Education in Indonesia . Jakarta: Directorate. General of Higher Education Ministry of National Education.

Sugiyono, 2009. Educational Research Methods Quantitative, Qualitative, and R\&D Approaches . Bandung: Alfabeta.

Tegeh, Made, et al. 2014. Development Research Model . Yogyakarta: Graha knowledge.

Ahmad, A. B. (2018). Citra Destinasi Dan Pengaruhnya Terhadap Intensi Untuk Berkunjung Kembali Di Sulawesi Selatan Sebagai Destinasi Pariwisata. Sosiohumaniora, 20(3), 207-214.

Ariyanto. (2005). Ekonomi Pariwisata.
Jakarta: Penerbit Rineka Cipta

Charo, N., Sharma, P., Shaikh, S., Haseeb, A., dan Sufya, M. Z. (2015). Determining the Impact of E-wom on Brand Image and Purchase Intention through Adoption of Online Opinions. 3(1).

Chen, C and Tsai, D. (2007). Manajemen Pemasaran Jasa. Kelompok Gramedia: indeks.

Cheung, C. M \& Lee, M. K. (2012). What drives consumers to spread electronic word of mouth in online consumer- opinion platforms. Decision support systems, 53(1), 218-225.f Interactive Advertising, Vol. 6 No. 2,pp. 1-6.

Deksono, Favian Rachmadi. (2017). Pengaruh Motivasi Wisata dan Electronic Word Of Mouth Terhadap Minat Berkunjung ke Daya Tarik Goa Pindul. Skripsi Universitas Sanata Dharma. Yogyakarta.

Dewi. Indriyani Ratna. (2018). Pengaruh Electronic Word Of Mouth, Citra Destinasi Dan Fasilitas Wisata Terhadap Keputusan Berkunjung Yang Dimediasi Oleh Respon Emosional (Studi pada Pengunjung Wahana Air Lampung Walk Bandar Lampung). Skripsi Universitas Lampung Bandar Lampung.

Echtner, Charlotte M dan J.R. Brent Ritchie. (2003). The meaning and measurement of destination image.

The journal of tourism studies vol.14, no.1 may 03. Canada

Fitroh, S. K. A., Hamid, D., \& Hakim, L. (2017). Pengaruh Atraksi Wisata dan Motivasi Wisatawan Terhadap Keputusan Berkunjung (Survei pada Pengunjung Wisata Alam Kawah Ijen). Jurnal Administrasi Bisnis, 42(2), 18-25.

Ghozali, Imam. (2016). Aplikasi Analisis Multivariete Dengan Program IBM SPSS 23 (Edisi 8). Cetakan ke VIII. Semarang : Badan Penerbit Universitas Diponegoro.

Hailin, Qu., Kim, L.H., Im, H.H. (2011). "A model ofdestination branding: integreting the concepts of the branding and destination image", Tourism Management, Vol.32,pp. 465-475.

Hasan, A., \& Setiyaningtiyas, N. W. (2015). Pengaruh Electronic Word of Mouth pada Media Sosial Facebook terhadap Keputusan Berkunjung ke Desa Wisata Nglanggeran Gunungkidul. Jurnal Media Wisata: Wahana Informasi Pariwisata, 
13(1).

Hennig-Thurau, Kevin Gwinner., Gianfranco Walsh., and Dwayne Gremler. (2004). Electronic Word of Mouth Via Consumer Opinion Platform : What Motivates Consumers To Articulate Themselves on The Internet ?.Journal of Interactive Marketing.38:52.

Humaira, A., \& Wibowo, L. A. (2016). Analisis Faktor Elektronik Word Of Mouth (EWOM) Dalam Mempengaruhi Keputusan Berkunjung Wisatawan. THE Journal: Tourism and Hospitality Essentials Journal, 6(2), 1049-1060.

Jalilvand, M. R and Samiei, N. (2012). The Effect of Electronic Word Of Mouth on Brand Image and Purchase Intention: An Empirical Study in The Automobile Industry in Iran". Marketing Intelligence \& Planning, Vol. 30 No. 4, pp. 460-47

Keliwar, S., \&Nurcahyo, A. (2015). Motivasi dan Persepsi Pengunjung terhadap

Obyek Wisata Desa Budaya Pampang di Samarinda. Jurnal

Manajemen Resort dan Leisure, 12(2). Kotler, Philip, dan Gary Armstrong. (2001). Prinsip-

Prinsip Pemasaran. Edisi 12. Jakarta: Erlangga

Kotler, Philip, dan Gary Armstrong. (2004). Dasar-dasar pemasaran. Jakarta: PT Indeks

Kotler, Philip. (2005). Manajemen Pemasaran. Jilid I. Jakarta: PT.Indeks

Kusuma, I. G. A. R. D., \& Suryasih, I. A. 2016. Aktivitas Wisata Spiritual dan Motivasi Berwisata Di Daya Tarik Wisata Tanah Lot Kabupaten Tabanan. Jurnal Destinasi Pariwisata, 4(2), 118-122.

Malik. Moh. Ibram dan M. Kholid Marwadi. (2016). Penagrud City Branding "The Soul Of Madura dan terhadap Keputusan Berkunjung Ke Kabupaten Sumenep. Jurnal Administrasi Bisnis. Vol. 37. (Agustus) No. 1

Mcdaniel, Lamb dan Hair. (2001). Pemasaran Buku Satu. Jakarta: Salemba Empat

Mowen, John C dan Michael Minor. (2002), Perilaku Konsumen (Jilid 1), Edisi Kelima. Jakarta: Erlangga.

Oka A. Yoeti. (2008). Perencanaa dan pengembangan pariwisata. Jakarta: PT Pradnya Paramita

Peter, J Paul dan Jerry C Olson. (2000). Perilaku Konsumen dan Strategi Pemasaran. Edisi
4, jilid 1. Jakarta: Erlangga

Republik indonesia. (2009). Undang - Undang

No. 11 Tahun 2009 Tentang

Kepariwisataan. Lembaran Negara republik indonesia tahun 2009. No 11

Sekertariat Negara: Jakarta

Sangadji, E.M dan Sopiah. (2013). Prilaku Konsumen: Pendekatan Praktis Disertai: Himpunan Jurnal Penelitian. Yogyakarta: Penerbit Andi 